\title{
暖地におけるチャ早生品種の品質特性（第2 報）
}

農林水産省茶業試験場札崎支場

和田光环 -中田典男* - 本荘吉男

\section{Tne Green Tea Quality of Early Varieties in the Warm Region (Part 2)}

\author{
By Kosei wada, Norio Nakata and Yoshio Honjo \\ Makurazaki Branch, National Research Institute of Tea
}

\section{1 ま がき}

暖地とくに南九州などにおける早生品種の導入は, 温 暖な気象条件と㻊霜害の少ない立地条件を生かして，早 出し新茶を出荷するために，また早・中・晚生品種の組 合せによる摘採労力の調整や工場操業ピークの解消など のためにも重要な間題である。

そこで，1972 年に早生品種として6品種をとりあげ， 対热をやぶきたとし，一番茶の製茶品澌を枕崎市周辺の 農家茶園について調查し，その結果を報告した。この第 1 報ては，製茶品質はするがわせ，くりたわせ，ゆたか みどりがすぐれ，やえ活，まきのはらわせ，はつみどり が劣ること，また摘採期の早晚等を考えれば，漫地向き 早生品種としてくりたわせ，ゆたかみどりがあげられる ことなどを明らかにした。しかし，この結果は単年度の 調査でああり，さらに上記の供試品種をするがわ世， くりたわせ，ゆたかみどりの3品種にしばって，1973， 1975年の 2 力年にわたり，製茶品質と化学成分括よびそ の年次間苃異などを検討した。ここでは第 1 報に和ける 1972年のこの3品種についての結果す含め，3 个年の調 查として報告する。な和 1974年す調查する予定であった が，3月下旬执よび4月上旬に連続して晚霜があり，調 查不能となった。この報告の一部は 1974 年 10 月の茶業 技術研究発表会て発表した。

\section{2 方法}

くりたわせ，ゆたかみどり，するがわせの3 品種につ いて，やぶきたを対照として調査した。1973 年は枕崎市 周辺の 1972年と医漂同一場所て，〔くりたわせ，ゆたかみ どり，するがわせの 5 年生の農家茶婮を選定し，やぶ きたは場内茶園のあのを用いた。1975 年はいずれる場内
の 5 年生茶圆を用い陚験区は 1 区 $72 \mathrm{~m}^{2}$ て，3区制とし た。

調查万法は第 1 報とほほ同様で，一番茶期に早期と適 期の 2 回に分けて手摘みし，茶芽の状態を調査するとと もに，八木式 $2 \mathrm{~K}$ 機を用い，嫩準製造法によって2反復 の製茶をし，その品質怙よひ化学成分を調查・分析し た。また1975年には生葉収量および荒茶量を調查した。

\section{3 結 果と考察}

\section{1 摘採期ならびに生育状況}

調査した年度の気象概況はつぎのよ5であった。1972 年は暖冬異変の気象で，3月上旬は気温が低下したが， 中下旬は平年よりす高温で，萌芽期は早まったが，4月 2 日の暴常低温で著しい凍霜害をらけた。

また，1973 年も暖冬の気象で，3 月上旬は平年にくら べ低温でったが，中旬以降は高温となり，4月上旬に は気温が急上昇し，降水量す平年にくらべて多く，萌芽 期も早まり，近年にないよい生育を示した。

1975 年は $1 \sim 3$ 月の冷光込みが敛しく，とくに 2 月中 〜下旬にか付て異常低温で，その後平年並かやや高めに 経過したが，3月中〜下旬に再び寒波があり，たびたび 強霜があった。このため萌芽期は遅れ，4月に入っても 上旬の冷え込みが強く，茶芽の生育に悪影響を及ぼし， 摘採期遲れた。

調查園について, 1972 年は 4 月 2 日の異常低温です， ほとんどその被害を認めなかった。しかし 1975年は3月 22 日に降霜があり，4月1，2 日にあられが降るなどの 異常気象て，茶芽の生育にす悪影響を与えた。

摘採期の出開度は表 1 のと扣りで，適期と思われたと きの出開度は品種や年度によってかなりまちまちであっ たが，摘採適期は図 1 のうであった。霜害のなかった 
表 1 摘 採 期 $の$ 出開度 (\%)

\begin{tabular}{|c|c|c|c|c|c|c|c|}
\hline \multirow{2}{*}{ 品 } & \multirow{2}{*}{ 摘採期 } & \multicolumn{2}{|c|}{1972} & \multicolumn{2}{|c|}{$\begin{array}{llll}1 & 9 & 7 & 3\end{array}$} & \multicolumn{2}{|c|}{1975} \\
\hline & & 月 & 出 開 度 & 月 $\quad$ 日 & 出開度 & 月 & 出開度 \\
\hline \multirow{2}{*}{ くりたわせ } & & \multirow{2}{*}{$\begin{array}{l}4.7 \\
4.13\end{array}$} & 14.0 & \multirow{2}{*}{$\begin{array}{l}4.4 \\
4.13\end{array}$} & 5.0 & \multirow{2}{*}{$\begin{array}{l}4.18 \\
4.21\end{array}$} & 13.3 \\
\hline & 適 & & 38.5 & & 44.0 & & 20.0 \\
\hline \multirow{2}{*}{ ゆたかみどり } & 早 & \multirow{2}{*}{$\begin{array}{l}4.12 \\
4.18\end{array}$} & 23.0 & \multirow{2}{*}{$\begin{array}{l}4.12 \\
4.16\end{array}$} & 23.0 & \multirow{2}{*}{$\begin{array}{l}4.21 \\
4.23\end{array}$} & 37.5 \\
\hline & 期 & & 50.6 & & 58.0 & & 41.0 \\
\hline \multirow{2}{*}{ するがわせ } & 早 & \multirow{2}{*}{$\begin{array}{l}4.17 \\
4.24\end{array}$} & 10.2 & \multirow{2}{*}{$\begin{array}{l}4.20 \\
4.25\end{array}$} & 24.0 & \multirow{2}{*}{$\begin{array}{l}4.23 \\
4.25\end{array}$} & 20.0 \\
\hline & 適 & & 30.0 & & 55.0 & & 26.0 \\
\hline \multirow{2}{*}{ やぶきた } & & 4.21 & 18.7 & 4.17 & 24.0 & \multirow{2}{*}{$\begin{array}{l}4.26 \\
4.28\end{array}$} & 29.0 \\
\hline & 適 & 4.26 & 46.9 & 4.21 & 40.0 & & 45.0 \\
\hline
\end{tabular}

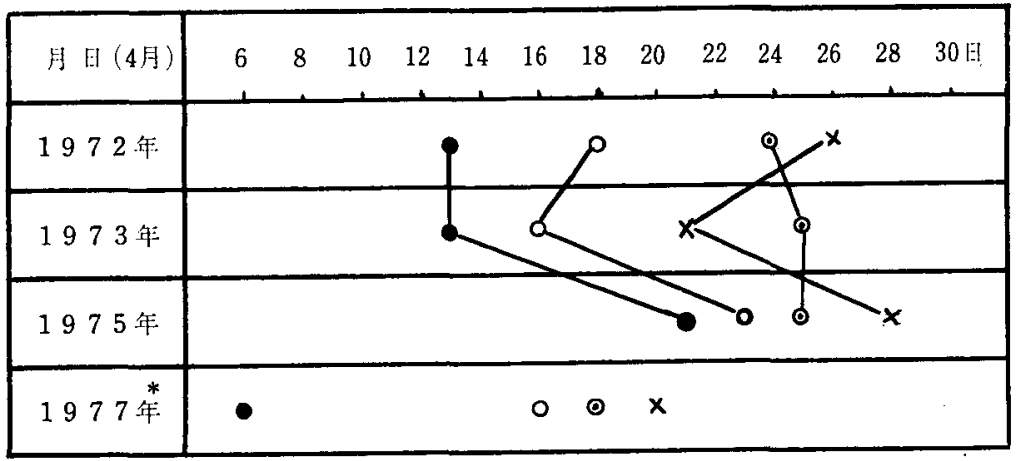

図 1 品種別摘採適期

*) 家弓らの調查結果

注)

くりたわせ ○沛たかみどり

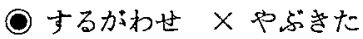

\section{2 製 茶品 質}

(1) 審 查 結 果 したが，これにくらべ，1973 年は籍害はなかったが， くりたわせ，主るがわせが 1 週間程度荤れ，しかも， さるがわせはやぶきたよりる遮れていた。また1972年は くりたわせ，するがわせ，やぶきたが6〜7日，1975 年 はくりたわせが 2 週闑，步たかみどり，するがわせ，や ぶきたが1週間程度遅れたことになり，とくにくりたわ 世の荤れが大きく，これは前述の気像条件によるすのと 思われた。このよ5な摘採適期は年次化よって若干異な ったが，1973 年にするがわせの摘採適期がやぶきたより 遅れた活かは，各年次ともくりたわせがもっともはや く，ついでゆたかみどり，するがわせ，やぶきたの順で あった。つぎ 1975 年に調査した生葉収量 $(\mathrm{kg} / 10 \mathrm{a})$ と 荒茶量 $(\mathrm{kg} / 10 \mathrm{a})$ は表2のとおりで，単年度の結果であ り，むた霜害の影響もいくらか考元られるが，生葉収量 执上び荒茶量は早期，適期摘みともゆたかみどりがも。 とも多く，ついでやぶきた，士るがわせ，くりたわせの 順に少なかった。
茶の審査成績は表 3 拈よび図 2 ，またその分散分析㧊 上び有意差検定結果は表 4，5のとおりであった。

図2のよ5に，早期と適期の品質差は 1977年のゆたか みどりの外観と内質，1973 年のくりたわせの内質を除い て大きな差異はみられず，全体的にみて，くりたわせは 早期，尘たかみどりは適期の品質がよかった。第 1 報で 述べたよ $5 に ， 1972$ 年のゆたかみどりの早期が適期より あ品質が劣ったのは熟度が若過ぎたためではないかと思 われた。しかし里たかみどりの外観は 1975 年は 1972 年 と同様に適期が早期よりるよかったが，1973 年は早期が 適期よりもよく，その傾向が翼なった。をたするがわせ は外観は良いが，内質が劣り，里たかみどりは外観，内 質とも少る傾向がみられた。

審查成續の分散分析は表 4 のとおりで，外観，内質， 合計点とも品種と年次に有意差が認められ，その検定結 果は表 5 のと打りであった。

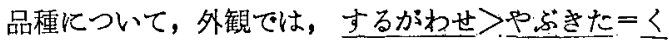




\begin{tabular}{|c|c|c|c|c|c|c|c|}
\hline \multirow{2}{*}{ 品 } & \multirow{2}{*}{ 摘採期 } & \multirow{2}{*}{$\frac{\text { 生 葉 }}{(\mathrm{kg})}$} & \multirow[t]{2}{*}{ 量 } & \multirow{2}{*}{$\begin{array}{c}\text { 製茶步 } \\
(\%)\end{array}$} & 蓅 & \multicolumn{2}{|r|}{ 量 } \\
\hline & & & & & $(\mathrm{kg})$ & 指 & 数 \\
\hline \multirow{2}{*}{ くりたわせ } & & 177.6 & 81 & 19.1 & 33.9 & & 78 \\
\hline & 適 & 192.4 & 88 & 20.0 & 38.5 & & 88 \\
\hline \multirow{2}{*}{ ゆたかみどり } & 早 & 222.0 & 102 & 20.0 & 44.4 & & 102 \\
\hline & 適 & 244.2 & 112 & 21.4 & 52.3 & & 120 \\
\hline \multirow{2}{*}{ するがわせ } & 早 & 188.7 & 86 & 20.0 & 37.7 & & 86 \\
\hline & 期 & 214.6 & 93 & 20.0 & 42.9 & & 98 \\
\hline \multirow{2}{*}{$\ngtr$ \& きた } & 早 & 196.1 & 90 & 20.0 & 39.2 & & 90 \\
\hline & 適 & 218.3 & 100 & 20.0 & 43.7 & & 100 \\
\hline
\end{tabular}

表3 茶 の 番査成績

\begin{tabular}{|c|c|c|c|c|c|c|c|c|}
\hline 年次 & 種 & 適採期 & 形 状 & 色 沢 & 香気 & 水 & 滋 & 合 \\
\hline \multirow{8}{*}{1972} & \multirow{2}{*}{ くりたわせ } & 早 期 & 16.0 & 17.0 & 15.8 & 18.0 & 17.8 & 84.6 \\
\hline & & 適 期 & 16.0 & 17.5 & 17.0 & 17.0 & 17.0 & 84.5 \\
\hline & \multirow{2}{*}{ ゆたかみどり } & 早 期 & 16.5 & 15.0 & 16.5 & 14.5 & 15.5 & 78.0 \\
\hline & & 適 期 & 18.0 & 17.5 & 17.5 & 16.5 & 16.5 & 86.0 \\
\hline & \multirow{2}{*}{ するがわせ } & 早 期 & 19.0 & 18.0 & 17.0 & 17.0 & 16.5 & 87.8 \\
\hline & & 適 期 & 19.0 & 18.0 & 18.0 & 16.3 & 17.0 & 88.3 \\
\hline & \multirow{2}{*}{ やぶたた } & 早 期 & 18.8 & 16.0 & 17.5 & 18.0 & 17.3 & 87.6 \\
\hline & & 適 期 & 17.8 & 15.5 & 17.3 & 17.8 & 17.8 & 86.2 \\
\hline \multirow{8}{*}{1973} & \multirow{2}{*}{ くりたわせ } & 早 期 & 19.0 & 19.0 & 18.5 & 18.8 & 18.8 & 94.1 \\
\hline & & 適 期 & 17.5 & 18.3 & 17.0 & 17.0 & 16.8 & 86.6 \\
\hline & \multirow{2}{*}{ ゆたかみどり } & 早 期 & 17.5 & 16.5 & 17.0 & 18.0 & 17.0 & 86.0 \\
\hline & & 適 期 & 17.0 & 16.0 & 16.3 & 18.3 & 17.5 & 85.1 \\
\hline & \multirow{2}{*}{ するがわせ } & 早 期 & 19.0 & 17.0 & 17.0 & 18.8 & 17.0 & 88.8 \\
\hline & & 適 期 & 17.5 & 17.0 & 16.3 & 19.0 & 18.0 & 87.8 \\
\hline & \multirow{2}{*}{ やぶた } & 早 期 & 18.5 & 19.0 & 18.0 & 19.0 & 17.5 & 92.0 \\
\hline & & 適 期 & 18.0 & 18.0 & 18.0 & 19.0 & 18.5 & 91.5 \\
\hline \multirow{8}{*}{1975} & \multirow{2}{*}{ くりたわせ } & 早 期 & 18.0 & 19.0 & 19.0 & 18.5 & 19.0 & 93.5 \\
\hline & & 適 期 & 17.8 & 18.5 & 18.3 & 18.5 & 18.0 & 91.1 \\
\hline & \multirow{2}{*}{ ゆたかみどり } & 早 期 & 16.0 & 17.0 & 16.0 & 17.0 & 16.0 & 82.6 \\
\hline & & 適 期 & 16.3 & 17.8 & 16.0 & 17.0 & 16.0 & 83.1 \\
\hline & \multirow{2}{*}{ するがわせ } & 早 期 & 20.0 & 19.8 & 17.5 & 17.5 & 16.8 & 91.6 \\
\hline & & 適 期 & 20.0 & 19.8 & 15.0 & 19.0 & 17.3 & 91.1 \\
\hline & \multirow{2}{*}{ やら゙きた } & 早 期 & 18.0 & 18.0 & 18.0 & 18.3 & 18.3 & 90.6 \\
\hline & & 適 期 & 17.0 & 19.0 & 17.3 & 19.0 & 18.0 & 90.3 \\
\hline
\end{tabular}

注） 2 反復製造したものの平均値である。 

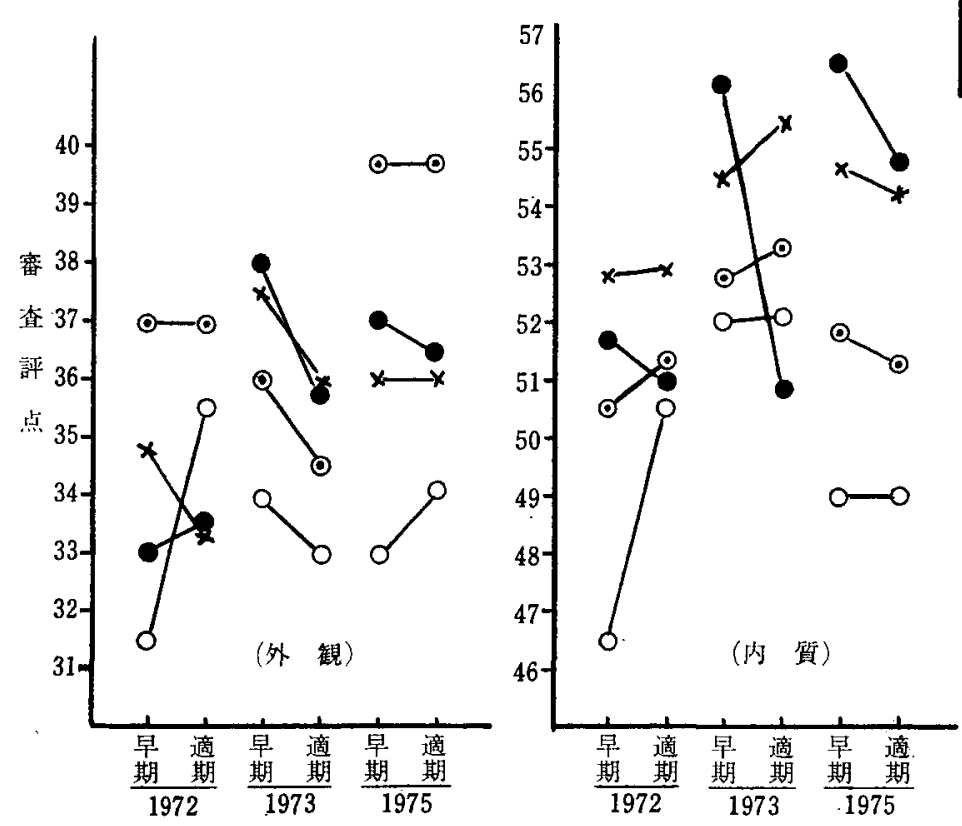

$$
\begin{aligned}
& \text { ○くりたわせ } \\
& \text { ○わたかみどり } \\
& \text { ○するがわせ } \\
& \text { メやふをた }
\end{aligned}
$$

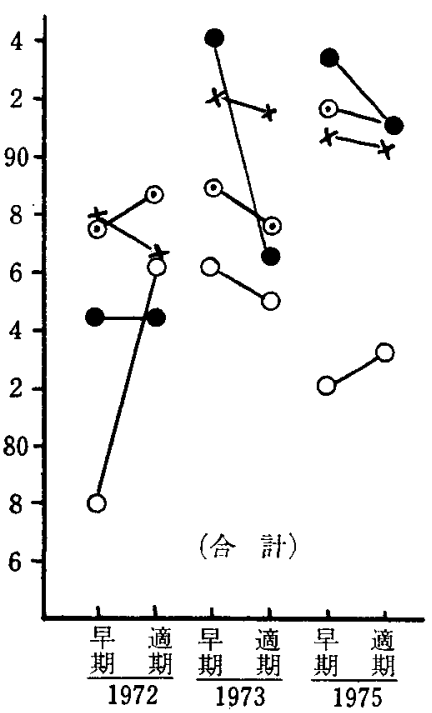

図2製茶品質の年次品種間差異

\begin{tabular}{|c|c|c|c|c|c|c|c|c|c|}
\hline \multirow{3}{*}{ 項 目 } & \multicolumn{4}{|c|}{ 要 } & \multicolumn{5}{|c|}{ 因 } \\
\hline & & 採 & \multicolumn{2}{|l|}{ 品 } & \multicolumn{2}{|c|}{ 種 } & \multicolumn{2}{|l|}{ 年 } & \multirow{2}{*}{$\frac{\text { 次 }}{1975}$} \\
\hline & $\begin{array}{c}\text { 適期 } \\
(35.4)\end{array}$ & $\begin{array}{c}\text { 早期 } \\
(35.6)\end{array}$ & $\begin{array}{c}\text { ゆたかみどり } \\
(33.5)\end{array}$ & $\begin{array}{c}\text { くりたわせ } \\
(35.6) \\
\end{array}$ & $\begin{array}{c}\text { や芯た } \\
(35.6)\end{array}$ & $\begin{array}{c}\text { するがわせ } \\
\text { (37.4) }\end{array}$ & $\begin{array}{c}1972 \\
(34.5)\end{array}$ & $\begin{array}{c}1973 \\
(35.6) \\
\end{array}$ & \\
\hline 内 & $\begin{array}{c}\text { 適期 } \\
(52.2)\end{array}$ & 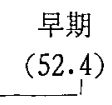 & $\begin{array}{c}\text { ゆたかみどり } \\
(49.9)\end{array}$ & $\begin{array}{c}\text { するがわせ } \\
(51.8) .\end{array}$ & $\begin{array}{c}\text { くたわせ } \\
(53.5)\end{array}$ & $\begin{array}{c}\text { や゙きた } \\
(54,1)\end{array}$ & $\begin{array}{c}1972 \\
(50.9)\end{array}$ & $\begin{array}{r}1975 \\
(52.7) \\
\end{array}$ & $\begin{array}{c}1973 \\
(53.4) \\
\end{array}$ \\
\hline 合 計 & $\begin{array}{c}\text { 適期 } \\
(87.6) \\
\end{array}$ & $\begin{array}{c}\text { 早期 } \\
(88.0)\end{array}$ & $\begin{array}{c}\text { ゆたかみどり } \\
(83.4)\end{array}$ & $\begin{array}{c}\text { くりたわせ } \\
(89.1)\end{array}$ & $\begin{array}{c}\text { するがわせ } \\
(89.2)\end{array}$ & $\begin{array}{c}\text { や心 た } \\
(89.7)\end{array}$ & $\begin{array}{c}1972 \\
(85.3)\end{array}$ & $\begin{array}{c}1973 \\
(89.0) \\
\end{array}$ & $\begin{array}{r}1975 \\
(89.2) \\
\end{array}$ \\
\hline
\end{tabular}

表 4 審 查成 績 $の$ 分散分析

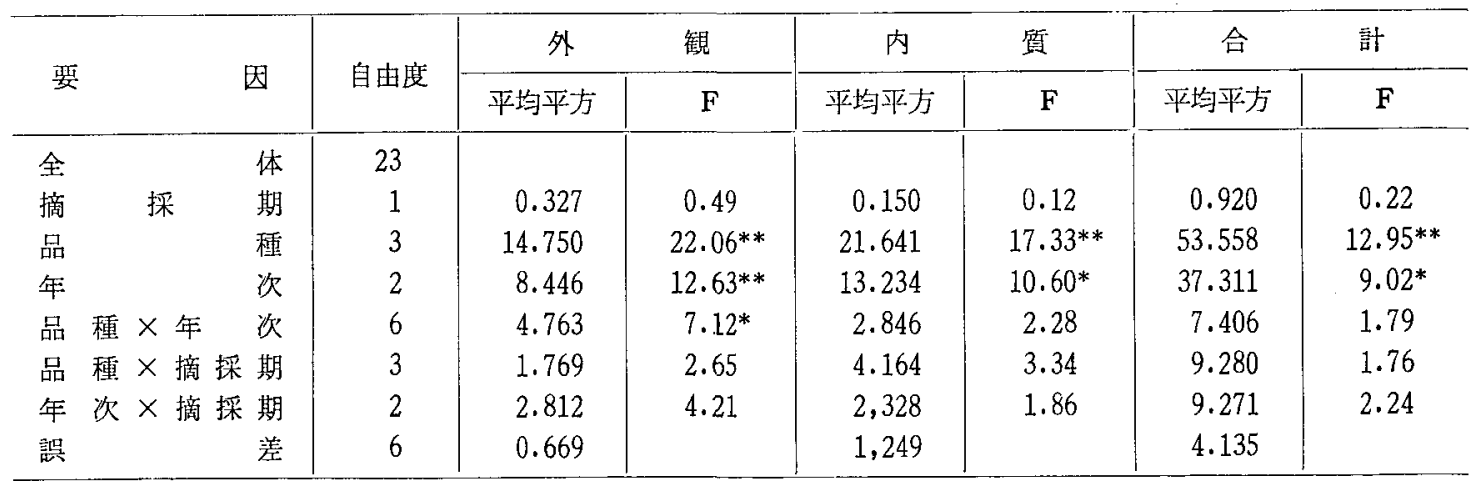

表 5 審査成 績 の有意差検定

注）Duncan の多重検定で検定し，（）の数字は平均值， アンダーラインは有意でないものを示す。 
りたわせ〉里たかみどりでするがわせがあっとあよく， 内質で，や占きた＝くりたわせ〉するがわせ〉他たか みどりの順位となり，審查合計点では，やぶきた二する がわせ二くりたわせ〉生たかみどりで，するがわせとく りたわせはやぶきたと同程度の品質であったが，里たか 圣どりはこれらより劣った。これらを第 1 報の結果とく らべると，外钼では，士るがわせは第 1 報と同様にもっ

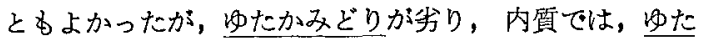

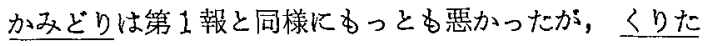
わせがよく，するがわせが少った。また合計では，吊た かみどりは第 1 報と同樣に少ったが， くりたわわがよか った。このように第 1 報の結果とあまり大きな差異はみ られなかった。

年次にうしては 1975 年 $=1973$ 年>1972 年の結果とな った。なお品種と年度の交互作用に有意差が認められた が，これは前述のように济たかみどりの早期と適期にお ける外観の良否の傾向が年次によって暴なることによる ものと思われる。

(2) 品種別の品質特性

官能審查からみた品種別の品暂特性は， 3 力年を通じ て，汪深一定した特徽が認められ，第 1 報に述べたよう に，〈りたわせは品種特有の香気と特殊ならまみがあ り，とくに早期摘みで品種の特徽が引きたつよ5であっ た。するがわせは形状がよく，とくに早期摘みは細上れ して非常に良いが，色沢は幾分あめ色を带びる傾向があ り，滋味もやや淡白であった。すたゆたか子どりは早期 摘みで，ペコーが目立ち，色沢もややあめ色を带びる傾
向があるが，適期摘みはペコーの目立ちが少なく，色沢 も濃緑で滋味も濃厚となり, 品種の特性が強く出るよう であった。

\section{3 化 学 成 分}

化学成分の分析結果を図 3 および表 6 に，またその分 散分析と有意差検定結果を表 $7 ， 8$ 亿そ机ぞれ示した。

図 3 の上 5 K, 全 $\mathrm{N}$ は全体的に 1972年の含量が低く, 1972年のゆたかみぞり，1973 年のやぶきたを除いて，第 1 報と同様保，早期よりす適期での合量が少なく，表 7 の分散分析でも摘採期に有意差が認められ，表 8 の上 5 に早期〉適期であった。また年次に有意差がみられ，19 75 年> 1973 年>1972 年であったが，品種による有意差 は想められなかった。

タンニンは図 3 に示すよ5に, 全体的にみて，1973 年 の含量が低く，第 1 報と同様に，摘採期による差異につ いて一定した傾向はみられなかった。分散分析の結果， 品種と年㳄間に有意差があり，その検定結果は品種につ いては，黑たかみどり=するがわせ〉やぶきた＝くりた わせで，肿たかみどりとするがわせの含量が多かった。

アミノ酸含量は表6のとおりで，士るがわせが少なか ったが，分散分析の結果，品種による有意差はみられな かった。しかし第1報のよ5に，电たかみどりはアミノ 酸含星が多い傾向にあった。

\section{4 製茶品質と化学成分の関係}

図 4 亿早期と適期摘みの平均值で，全窒素と内質拉上 び溪味点数の関係を示したが，全体的にみて，はっきり した㑯向は認められなかった。しかし年度別にみると，
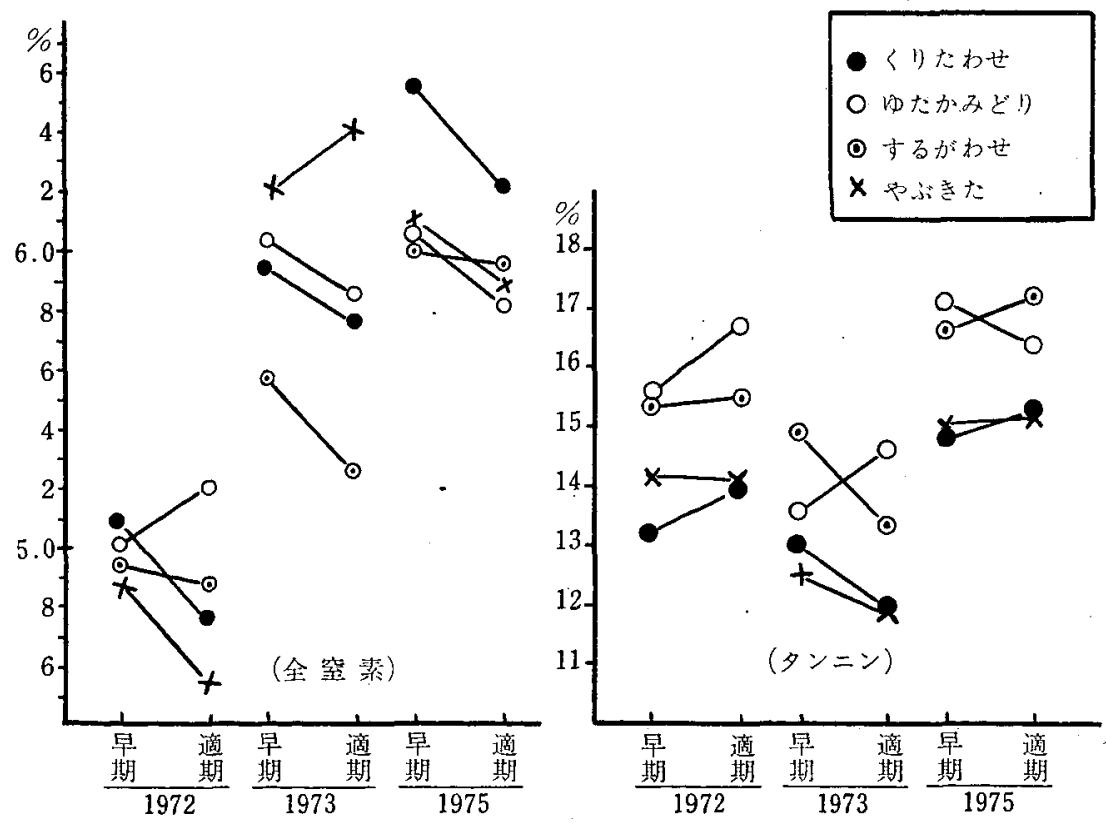

因 3 全䇪素打よびタンニン含量の年次品種間差異 
表6 アミノ酸分析值

\begin{tabular}{|c|c|c|c|c|c|c|c|c|c|c|}
\hline 品 種 名 & 年 次 & 出開度 & 全窒素 & $\begin{array}{l}\text { ア } \\
=\end{array}$ & $\begin{array}{l}\text { アスパラ } \\
\text { ギン 酸 }\end{array}$ & セリン & テアニン & $\begin{array}{l}\text { グルタ } \\
\text { ミ゙酸 }\end{array}$ & \multicolumn{2}{|c|}{ 合' 計 値* } \\
\hline \multirow{3}{*}{ くりたわ世 } & 1972 & 38.5 & .4 .76 & 443.3 & 112.0 & 148.6 & 1976.3 & 304.6 & 3106 & 108 \\
\hline & 1973 & 44.0 & 5.77 & 269.0 & 198.6 & 220.6 & 2586.2 & 228.6 & 3683 & 92 \\
\hline & 1975 & 20.0 & 6.22 & 258.8 & 153.6 & 158.9 & 1674.9 & 261.7 & 2612 & 113 \\
\hline \multirow{3}{*}{ ゆたかみどり } & 1972 & 50.6 & 5.19 & 834.3 & 157.0 & 267.5 & 2886.1 & 298.6 & 4593 & 159 \\
\hline & 1973 & 58.0 & 5.85 & 388.0 & 190.0 & 244.2 & 2460.8 & 280.7 & 3696 & 92 \\
\hline & 1975 & 41.0 & 5.81 & 217.2 & 108.7 & 186.0 & 1831.6 & 248.6 & 2728 & 118 \\
\hline \multirow{3}{*}{ するがわ } & 1972 & 30.0 & 4.88 & 86.1 & 128.3 & 137.5 & 1307.0 & 223.9 & 2013 & 70 \\
\hline & 1973 & 55.0 & 5.27 & 97.6 & 140.8 & 214.2 & 1968.6 & 186.9 & 2733 & 68 \\
\hline & 1975 & 26.0 & 5.94 & 95.2 & 143.9 & 135.4 & 1237.0 & 249.0 & 1994 & 86 \\
\hline \multirow{3}{*}{ や岕きた } & 1972 & 46.9 & 4.53 & 175.7 & 113.8 & 229.3 & 2035.6 & 214.6 & 2874 & 100 \\
\hline & 1973 & 40.0 & 6.40 & 284.3 & 219.2 & 335.4 & 2785.1 & 239.8 & 3988 & 100 \\
\hline & 1975 & 45.0 & 5.87 & 81.1 & 122.6 & 186.4 & 1522.3 & 258.7 & 2310 & 100 \\
\hline
\end{tabular}

注）(1）適期の試料についての分析值である。

(2) *右側の数值は各年次のやぶきたを 100 とした指数。

表 7 化学成分の分散分析

\begin{tabular}{|c|c|c|c|c|c|c|c|c|c|c|c|}
\hline \multirow{2}{*}{ 要 } & \multirow{2}{*}{\multicolumn{2}{|c|}{ 因 }} & \multicolumn{2}{|c|}{ 全 } & \multirow{2}{*}{$\frac{\text { 素 }}{F}$} & \multicolumn{2}{|c|}{ タ } & \multirow{2}{*}{$\frac{Y}{F}$} & \multicolumn{3}{|c|}{$\boldsymbol{~}$} \\
\hline & & & 自由度 & 平均平方 & & 自由度 & 平均平方 & & 自由度 & 平均平力 & F \\
\hline 全 & & 体 & 23 & & & 23 & & & 11 & & \\
\hline 摘 & & 採 & 1 & 0.144 & $6.21^{*}$ & 1 & 0.006 & 0.04 & - & - & - \\
\hline 品 & & 種 & 3 & 0.098 & 4.24 & 3 & 6,598 & $41.04^{* *}$ & 3 & 1.038 & 3.97 \\
\hline 年 & & 次 & 2 & 3.110 & $134.05^{* *}$ & 2 & 14,593 & $90.77^{* *}$ & 2 & 1.280 & 4.90 \\
\hline 品 & 種 & × 年 次 & 6 & 0.161 & 6.92 & 6 & 0.321 & 1.99 & 一 & - & - \\
\hline 品 & 種 & $\times$ 摘採期 & 3 & 0.011 & 0.48 & 3 & 0.207 & 1.28 & 一 & - & - \\
\hline 年 & 次 & $\times$ 摘採期 & 2 & 0.005 & 0.22 & 2 & 1.128 & 0.16 & 一 & - & - \\
\hline 愦 & & 差 & 6 & 0.023 & & 6 & 0.161 & & 6 & 0.261 & \\
\hline
\end{tabular}

注） †適期の試料について行った。

表8 化学成分 $の$ 有意差検定

\begin{tabular}{|c|c|c|c|c|c|c|c|c|}
\hline \multirow{2}{*}{ 項 目 } & \multicolumn{4}{|c|}{ 要 } & \multicolumn{2}{|l|}{ 因 } & \multirow{2}{*}{\multicolumn{2}{|c|}{ 次 }} \\
\hline & 摘 採 期 & 品 & & & 種 & 年 & & \\
\hline 全窒素 & $\begin{array}{cc}\text { 適期 } & \text { 早期 } \\
(5.53) & (5.69)\end{array}$ & $\begin{array}{c}\text { するがわせ } \\
(5.43) \\
\end{array}$ & $\begin{array}{c}\text { ゆたかみどり } \\
(5.66)\end{array}$ & $\begin{array}{c}\text { やぶき } \\
(5.66)\end{array}$ & $\begin{array}{c}\text { くりたわせ } \\
(5.72) \\
1\end{array}$ & $\begin{array}{c}1972 \\
(4.91)\end{array}$ & $\begin{array}{c}1973 \\
(5.88)\end{array}$ & $\begin{array}{c}1975 \\
(6.07)\end{array}$ \\
\hline タンニン & $\begin{array}{cc}\text { 適期 } & \text { 早期 } \\
(14.64) & (14.68) \\
1 & 1\end{array}$ & $\begin{array}{c}\text { くりたわせ } \\
(13.74) \\
1\end{array}$ & $\begin{array}{c}\text { やぶさた } \\
(13.78) \\
\end{array}$ & $\begin{array}{c}\text { するがわせ } \\
(15.49) \\
\end{array}$ & $\begin{array}{c}\text { ゆたかみどり } \\
(15.65) \\
1\end{array}$ & $\begin{array}{c}1973 \\
(13.20)\end{array}$ & $\begin{array}{c}1972 \\
(14.87)\end{array}$ & $\begin{array}{c}1975 \\
(15.93)\end{array}$ \\
\hline アミノ酸 & & $\begin{array}{c}\text { するがわせ } \\
(2246) \\
\end{array}$ & $\begin{array}{c}\text { やぶきた } \\
(3057)\end{array}$ & $\begin{array}{c}\text { くりたわせ } \\
\text { (3133) }\end{array}$ & $\begin{array}{c}\text { ゆたかみどり } \\
(3672) \\
1\end{array}$ & $\begin{array}{c}1975 \\
(2411) \\
\end{array}$ & $\begin{array}{c}1972 \\
(3147) \\
\end{array}$ & $\begin{array}{c}1973 \\
(3525) \\
\end{array}$ \\
\hline
\end{tabular}

注）Duncan の多重検定によった。（）の数字は平均値，アンダーラインは有意でないすのを示す。 


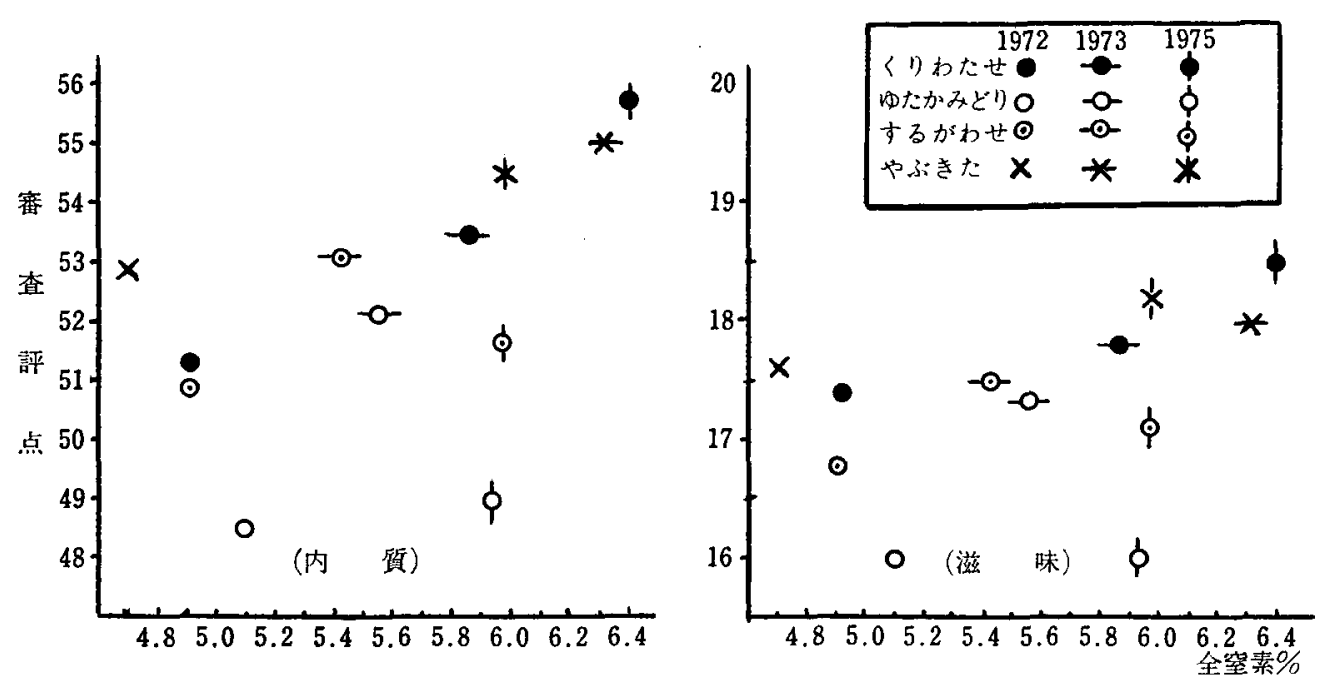

図4全窒素々内質括よび滋味評点の関係

注）早期と遥期の平均值

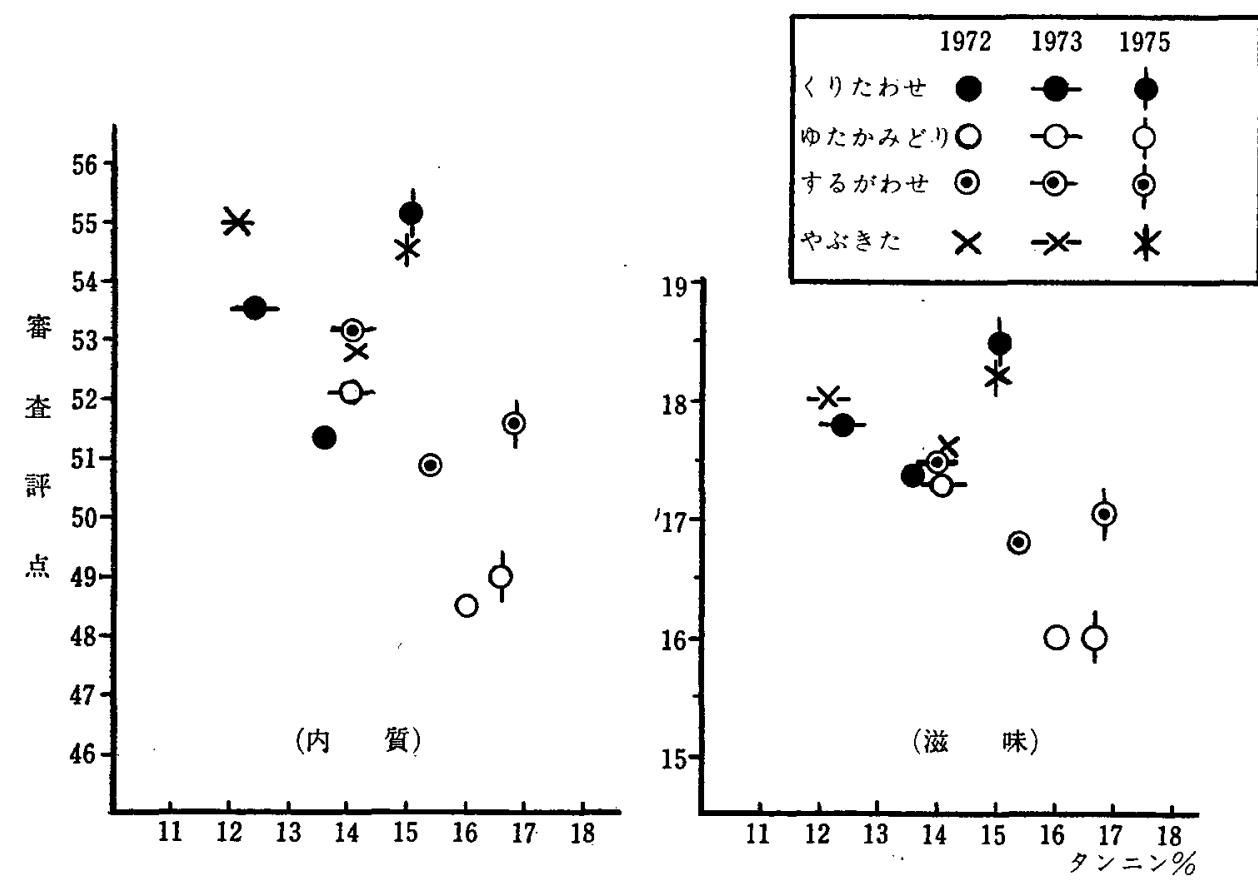

図 5 タンニン含量と内質および滋味評点の関係

注）早期と適期の平均值

1973 年と 1975 年については, 大体全窒素が少ないはど, 内質および滋味の点数が低くなる傾向がみられた。

次にタンニン含量と内質および聯味点数の関係を図 5 に示した。全体的に，また年度別にみてす，タンニン含 量が多い活ど内質および滋味点数は低くなる傾向が認 められた，各年次とる但たかみどりとするがわせはタン ニン含量が多く，内質および滋味点数が低かった前述の 内賈面の有意差がやぶきた二くりたわせ〉するがわせ
包たかみどりであった原因のひとつとして，タンニン含 量の差異が考克られる。

\section{4 総 合 考 察}

製茶品暨について，第1報では，全窒素および可溶性 窒素の多いものが, 製茶品齿はよかったが, この調查で は全窒素と製茶品賈の関係がはっきりしなかった。これ は全窒素の多い品種にしばったためと考えられる。 
また第 1 報では，タンニン含量と製茶品質の関係がは っきりしなかったが，この調査では，この関係が明らか にみられた。これも全窒素含量の多い品種にし活ったた

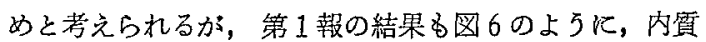
でまきのはらわせとはつみどり，滋味で事きのはらわせ を除けば，大体タンニン含量が多い浜ど内質抢よび滋味 点数は低くなる傾向が認められる。

中川らは化学成分を比較する場合，湴とんぞの成分含 量に年次による有意差が認められ，品種と年次の交互作 用にも有意差のあることから，品種による成分合量を比 較するためには，少くとも 3 年ぐらいの反復が必要であ
ることを認めているが，本調査でも，全窒素およびタン ニン含量には，いずれる年次による有意差が認められ， 試験の反復が必要であると思われた。とくに1872年につ いて，全N含量が低かったが，一方ンニン含量は 1973 年よりも多く，製茶品質も相詨的仁劣ることから：この 年の気象䓩件の影響ではないかと若えられる。

つぎ 1975年は前述のよ5な気象条件で，全般に摘採 期が遅れ，また生葉収量にもいくらか影響したと考兄ら れるが，聞取り調查による 産地取引洒格と荒茶量から各 品種ごとの粗収益を試算して表9に示した。

くりたわせ，必たかみどり，士るがわせの早期および
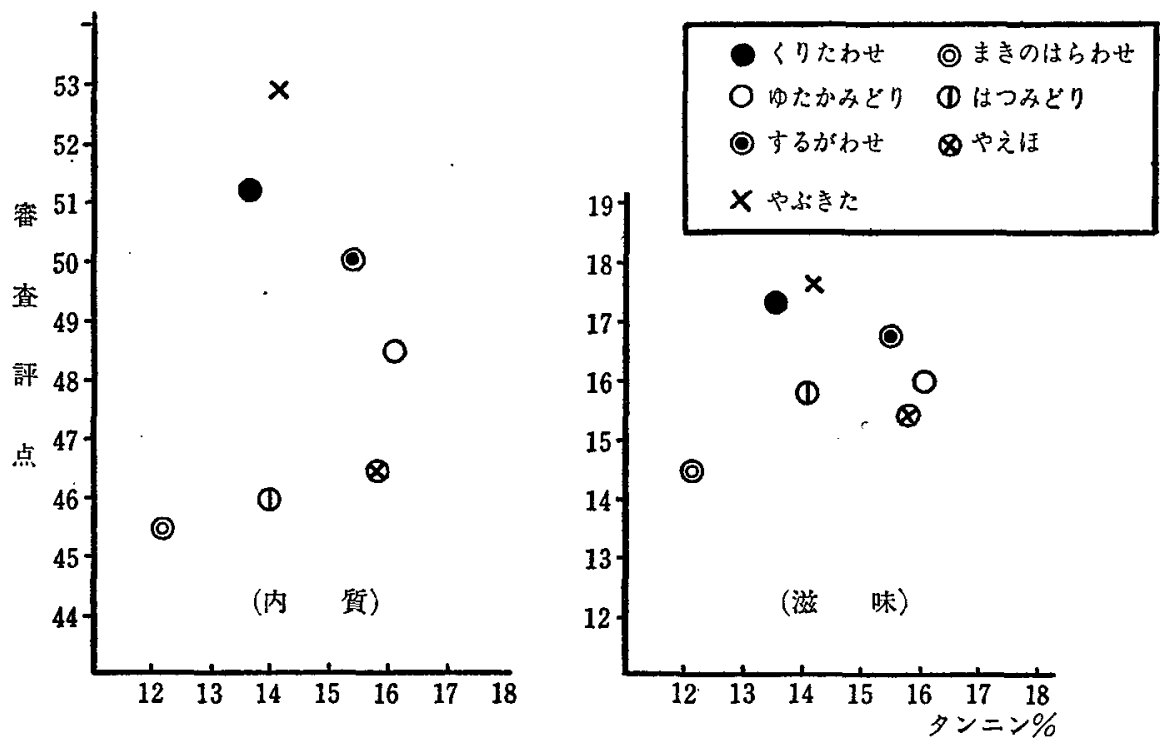

図6 タンニン含量と内質および滋味評点の関係（1972年）

注) 早期と適期の平均值

表 9 産地取引侕格と粗双益（1975年）

\begin{tabular}{|c|c|c|c|c|c|c|c|c|c|}
\hline \multirow{2}{*}{ 品 種 名 } & \multirow{2}{*}{\multicolumn{2}{|c|}{ 摘探期 }} & \multirow{2}{*}{ 月 日 } & \multirow{2}{*}{$\begin{array}{r}\text { 荒茶 量 } \\
\mathrm{kg} / 10 \mathrm{a}\end{array}$} & \multicolumn{2}{|c|}{ 取引価格 円/kg } & 粗 & \multicolumn{2}{|c|}{ 益 月/10a } \\
\hline & & & & & 金 額* & 指 数 & 金額 & 指 数** & 指 数*** \\
\hline \multirow[b]{2}{*}{ くりたわせ } & 早 & & 4.18 & 33.9 & 5,300 & 177 & 179,780 & 137 & 130 \\
\hline & & 期 & 4.21 & 38.5 & 3,800 & 127 & 146,220 & 112 & 100 \\
\hline \multirow{2}{*}{ ゆたかみどり } & 早 & & 4.21 & 44.4 & 3,500 & 117 & 155,400 & 119 & 90 \\
\hline & 適 & 期 & 4.23 & 52.3 & 3,300 & 110 & 172,460 & 132 & 100 \\
\hline \multirow{2}{*}{ するがわせ } & 早 & & 4.23 & 37.7 & 3,600 & 120 & 135,860 & 104 & 96 \\
\hline & & 期 & 4.25 & 42.9 & 3,300 & 110 & 141,640 & 108 & 100 \\
\hline \multirow{2}{*}{ やぶきた } & 早 & 期 & 4.26 & 39.2 & 3,300 & 117 & 137,270 & 105 & 105 \\
\hline & & 期 & 4.28 & 43.7 & 3,000 & 100 & 130,980 & 100 & 100 \\
\hline
\end{tabular}

注１）～工場での聞取りおよび珫崎市の資料による。

2） ** やぶきたの適期を 100 とした場合の指数。

3）*** 各品種の適期を 100 とした場合の指数。 
適期の取引価格はやぶきたの適期の取引価格よりいずれ も高く、とくにくりたわせの早期が高かった。これは時 期的に早かったためであるが，4月21日のくりたわせの 取引価格が同日の的たかみどりの早期のものより高いこ とは，品質も考慮して取引されていることを示してい る。粗収益はくりたわせの早期とゆたかみどりの適期が 多く，〈りたわせの場合は取引洒格が高いため，なた ゆたかみどりの場合は荒茶量が多いためである。

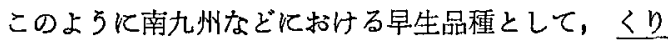
たわせが品質面怙よび早期出荷の点からもっとす有利と 思われた。しかし，第1報です述べたように，導入にあ たっては晚霜害が回避出来るかどうかの判断す重要であ ると考えられる。

\section{5 摘 要}

早生品種として，〈りたわせ，ゆたかみどり，するが わせの 3 品種をとりあげ，やぶきたを刘照とし，枕崎市 周辺および場内茶園について，一番茶の製茶品質を1972， 1973,1975 年の 3 力年にわたって調査した。

1）摘採適期は年次によって若干異なったが，各年次 ともくりたわせがもっとも早く，ついで里たかみどり， するがわせ，やぶきたの順であった。

2）製茶品質の合計点では，有意差検定の結果，やぶ きた二するがわせ二くりたわせ〉ゆたかみどり（良〉劣） の関係がみられた。

3）内質括よび滋味点数は，タンニン含量が多いほど 低くなる傾向がみられ，内質点数の有意差がやぶきた二 らりたわせ〉するがわせ〉生たかみどりであった原因の ひとつとして，タンニン含量の差異が考えられる。

4）内質拈よび滋味点数と全 N含量の関係はあきらか でかった。

5）温暖な南九州などにおける早生品種として，品質 面括よび早期出荷の点から，くりたわせがるっと西有利 と思われた。

本調查にあたり，茶園の選定について，御援助をいた たいた前枕崎市役所農務課参事永岩亥佐男氏，実施にあ たり御指導をいただいた前茶業試験埸炕崎支場辰坂本裕 博士（現茶業試験場製茶部長）および茶業試験場枕㥓支 場前原三利支場長ならびにとりまとめにあたり御助言を いたたいた 茶業試験場㶩崎支場鳥屋尾忠之博士に深く感 謝します。

\section{6 引用文 献}

1) 和由光正, 中田典男, 本荘吉男: 茶研報, No. 49, $47 \sim 55$ (1979).

2）家马実行，身屋尾忠之，黒木重光：茶研報，No. 47, 11 16 (1978).

3）中川致之，古谷弘三：荼技研，No. $48 ， 84 \sim 96$ (1975).

\section{Summary}

The green tea qualities of the first crops of Kuritawase, Yutakamidori and Surugawase (early varieties) were investigated in comparison with Yabukita (a medium variety), using the new shoots at the tea fields in the suburbs of Makurazaki City and in Makurazaki Branch, Kagoshima prefecture in 1972,1973 and 1975.

1) The optimum plucking time was earlier in the following order, Kuritawase $>$ Yutakamidori $>$ Surugawase $>$ Yabukita(eaily $>$ late).

2) The order of the tea quality was as follows, from the results of the sensory taste of the made tea : Yabukita $=$ Surugawase $=$ Kuritawase $>$ Yutakamidori (good>poor).

3) Total score of the liquor tasting and the score of the taste of the made tea by the sensory taste showed a tendency to decrease with the higher contents of the tannin. The differences in sensory scores of the liquor tasting are significant (Yabukita $=$ Kuritawase $>$ Surugawase $>$ Yutakamidori). Accordingly, the significant differences seemed to be due partly to the differences of the tannin contents.

4) The clear correlation was not observed between total nitrogen content and total score of the liquor tasting or the score of taste of the made tea by the sensory taste.

5) Kuritawase is recommended as the most suitable variety from the viewpoints of both better quality of the made tea and the earliest produc-tion among the early varieties in the warm region of sourthern Kyushu.

(Apr. 16, 1979) 